\title{
Kvalitative perspektiver på evalueringer i sundhedsvæsenet
}

Tidsskrift for Forskning i Sygdom og Samfund Nr. 15, 2011 


\section{Tidsskrift for Forskning i Sygdom og Samfund}

\section{Nr. 15: Kvalitative perspektiver på evalueringer $i$ sundhedsvæsenet \\ (C) 2011 forfatterne og udgiverne}

Redaktion:

Mette Bech Risør (ansv.), Forskningsenheden for Almen Praksis, Universitetet i Tromsø Torsten Risør, Allmennmedisin, Institutt for Samfunnsmedisin, Universitetet i Tromsø Gitte Wind, Afdeling for Antropologi og Etnografi, Aarhus Universitet

Ann Dorrit Guassora, Forskningsenheden for Almen Praksis, Københavns Universitet Susanne Reventlow, Forskningsenheden for Almen Praksis, Københavns Universitet Rikke Sand Andersen, Forskningsenheden for Almen Praksis, Aarhus Universitet

Gesteredaktører:

Ulf Kåre Jansbøl, Dansk Sundhedsinstitut, København

Katrine Schepelern Johansen, Institut for Antropologi, Københavns Universitet

Marius Brostrøm Kousgaard, Forskningsenheden for Almen Praksis, Københavns Universitet

Peer review foretages af et tværvidenskabeligt panel bestående af bl.a. læger, antropologer, filosoffer, historikere, psykologer, politologer og sociologer.

Proof: Emil Mølgaard Morell

Layout og prepress: Ea Rasmussen

Tryk: Werk Offset, Højbjerg

Udgiver:

Foreningen Medicinsk Antropologisk Forum

Afd. for Antropologi og Etnografi, Aarhus Universitet, Moesgård, 8270 Højbjerg

Bestilling og abonnement, henvendelser og hjemmeside:

Tidsskrift for Forskning i Sygdom og Samfund

Afd. for Antropologi og Etnografi, Aarhus Universitet, Moesgård, 8270 Højbjerg

Torsdag kl. 13.00-16.00, tlf. 89424597

Email: sygdomogsamfund@hum.au.dk

Hjemmeside: ojs.statsbiblioteket.dk/index.php/sygdomogsamfund

ISSN (tryk): 1604-3405

ISSN (online): 1904-7975

Tidsskriftet er udgivet med støtte fra Forskningsrådet for Kultur og Kommunikation.

Formål:

Tidsskrift for Forskning i Sygdom og Samfund er et tværfagligt tidsskrift, der tager udgangspunkt i medicinsk antropologi. Tidsskriftet har til formål at fremme og udvikle den forskning, der ligger i grænsefeltet mellem sundhedsvidenskab og humaniora/samfundsvidenskab. Tidsskriftets målsætning er at fungere som et forum, hvor disse fag kan mødes og inspirere hinanden - epistemologisk, metodisk og teoretisk - i forskellige forskningssammenhænge. Tidsskriftet formidler den debat og teoretiske udvikling, der foregår i de voksende faglige samarbejds- og forskningsinitiativer, der udspringer af dette grænsefelt. Tidsskriftet henvender sig til alle med interesse for forskning i sygdom og samfund og i særlig grad til sundhedsmedarbejdere i forsknings- og undervisningssammenhæng med forbindelse til tværfaglige miljøer.

Aims and scopes

The Journal for Research in Sickness and Society is an interdisciplinary journal which has a theoretical background in medical anthropology. The aim and purpose of the journal is to promote and develop research in the borderland between the health sciences and the humanities/the social sciences. The goal of the journal is to function as a forum in which these disciplines may meet and inspire each otherepistemologically, methodologically and theoretically. The journal conveys the debate and theoretical development which takes place in the growing collaboration and research initiatives emerging from this borderland. The journal addresses all with an interest in research in sickness and society and especially health professionals working with education and/or research in interdisciplinary institutions. 


\section{Indhold}

Kåre Jansbøl, Katrine Schepelern Johansen \& Marius Brostrøm Kousgaard

Introduktion 5

Kjeld Høgsbro

Evidensbaseret praksis - forhåbninger, begrænsninger og muligheder 11

Morten Hulvej Rod

Evidenssproget: Om sprog, viden og virkning i forebyggelse 31

Nichlas Permin Berger \& Karsten Vrangbæk

Kan MTV styrkes ved brug af realistisk evaluering?

- Udfordringer, barrierer og muligheder ved brug af realistisk evaluering til vurdering af komplekse behandlingsteknologier 55

Katrine Schepelern Johansen \& Kathrine Louise Bro Ludvigsen

Antropologiske evalueringer af misbrugsbehandling

- viden om kompleksitet, relationer og hverdagspraksis 77

Maria Laura Lippert

Kvalitetsmålinger i almen praksis: ny teknologi og gamle logikker 97

Morten Knudsen

Om grænser for kvalitetsteknologier - og om hvorfor det er vigtigt for kvalitetseksperter at reflektere over dem 121

\section{Peter Dahler-Larsen}

Om evalueringsbølgens samfundsmæssige dynamik og begrænsninger i nogle af de aktuelle evalueringssystemer 149

Abstracts in English 165

Forfatterliste 171

Skrivevejledning 173

Beskrivelse af nr. 16176 


\section{Kan MTV styrkes ved brug af realistisk evaluering?}

\section{Udfordringer, barrierer og muligheder ved brug af realistisk evaluering til vurdering af komplekse behandlingsteknologier}

Nichlas Permin Berger \& Karsten Vrangbæk

AKF - AnvendtKommunal Forskning

$n p b @ a k f . d k, k v @ i f s . k u . d k$

Berger, N.P. \& Vrangbæk, K. (2011). Kan MTV styrkes ved brug af realistisk evaluering? - Udfordringer, barrierer og muligheder ved brug af realistisk evaluering til vurdering af komplekse behandlingsteknologier. Tidsskrift for Forskning $i$ Sygdom og Samfund, nr. 15, 55-76.

Denne artikel diskuterer problemer med MTV-teori og -praksis særligt i forhold til komplekse, sociale teknologier. Det hævdes, at traditionelle statistisk baserede metodetilgange har begrænsninger i forhold til at analysere betydningen af den dynamiske organisatoriske kontekst for opnåelse af kliniske effekter. Dette betyder, at organisationsanalyserne i denne type MTVer bliver meget vigtige, og at de må baseres på andre typer teoretiske og metodiske tilgange. Artiklen diskuterer nyere udviklinger indenfor evalueringsteori, og særligt den kontekstfokuserede 'realistiske' evalueringstilgang som supplement til de hidtidigt anvendte organisationsteoretiske tilgange til MTV. Den teoretiske diskussion illustreres med eksempler fra en nyligt publiceret MTV om 'diabetiske fodsår' (Sundhedsstyrelsen, 2011). 


\section{Indledning og problem}

Verden over stræbes der efter at optimere leveringen og kvaliteten af serviceydelser i sundhedssektoren (Fulop et al., 2003). Mange lande har indført beslutningsunderstøttende instrumenter i sundhedssystemet med henblik på at træffe mere velunderbyggede beslutninger om indførelsen af nye behandlingsteknologier. Et udbredt eksempel er de såkaldte medicinske teknologivurderinger (MTV) ${ }^{1}$. MTV sigter mod at give et mere rationelt beslutningsgrundlag, men rummer også en række udfordringer i forhold til måden det gennemføres og anvendes på, særligt når genstandsfeltet er komplekse, sociale teknologier, hvor organiseringen af teknologi anvendelsen er helt central. Hensigten med denne artikel er at diskutere problemer med MTV-teori og -praksis særligt i forhold til komplekse sociale teknologier. Vi vil i forlængelse heraf diskutere om nyere udviklinger indenfor evalueringsteori, og særligt den kontekstfokuserede "realistiske" evalueringstilgang, kan supplere de organisationsteoretiske tilgange til MTV (Kristensen \& Sigmund, 2008).

Vi vil i artiklens anden del bruge illustrationer fra en nyligt publiceret MTV om "diabetiske fodsår" (Sundhedsstyrelsen, 2011)² til en empirisk understregning af pointer fra den mere teoretiske diskussion i artiklens første del.

En hyppigt anvendt definition beskriver MTV på følgende måde:

"a policy research that examines short- and long-term social consequences (for example societal, economic, ethical, legal) of the application of technology. The goal of [health] technology assessment is to provide policy makers with information on policy alternatives." (Banta \& Luce, 1993)

Selvom denne definition lægger op til ret brede vurderingskriterier anlægger de fleste MTVer i praksis et mere snævert perspektiv, hvor gyldighedskriterier hentes fra tankegangen om evidensbaseret medicin. Dette gælder især internationalt set, mens den danske MTV-tilgang fra starten har været præget af forskellige metodetilgange, som med forskellig vægt har præget udviklingen (jf. Kristensen \& Sigmund, 2008). Denne bredspektrede tilgang har i de senere år vundet stigende genklang internationalt (Kristensen \& Sigmund, 2008). Der er imidlertid stadig en vis usikkerhed i forhold til, hvordan man inddrager organisationsperspektiver, selvom der samtidigt er en stigende anerkendelse af, at den organisatoriske kontekst har betydning - også for de kliniske effekter af teknologi. RCTer ${ }^{3}$, som inddrager organisationsperspektiver, er imidlertid en mangelvare, og systematiske 
litteratur-reviews giver sjældent resultater om organisering, som med nogenlunde sikkerhed kan overføres til andre kontekster.

Ser man samlet på MTV, kan det påvises, at de fleste internationalt tilgængelige MTVer i perioden 1989-2002 i praksis baseres på systematiske litteraturgennemgange (Draborg et al., 2005). 92 \% af alle MTVer gennemført i denne periode byggede således på litteraturstudier. Til sammenligning blev selvstændig økonomisk evaluering gennemført i omkring $16 \%$, surveys blev anvendt i omkring $15 \%$ af alle MTVerne, og 'andre metoder' i omtrent $20 \%$. Der er for så vidt ikke noget underligt i denne vægt på litteraturgennemgange, fordi det hele tiden har været en grundidé med MTV, at man via gennemgang af eksisterende litteratur, skulle kunne nå til klare udsagn om konsekvenser ved forskellige teknologivalg. Problemet er, når antagelser og metoder til litteraturgennemgang for det kliniske felt også udstrækkes til at gælde de øvrige dele af MTV-perspektivet og særligt patient og organisationsanalysen, hvor det er langt vanskeligere at overføre resultater fra en kontekst til en anden. Teknologianvendelse i en kompleks organisatorisk kontekst har en dynamisk karakter, hvor teknologien til stadighed fortolkes og tilpasses af de relevante aktører, og efter de betingelser, som er til stede. Resultater opnås dermed kun under bestemte organisatoriske betingelser, som har både strukturelle, kulturelle og processuelle dimensioner, og som på grund af denne omfattende og dynamiske variabilitet kun med store forbehold kan sættes på formel. Den britiske forsker Jim Connelly bruger følgende eksempel (Connelly, 2001): Hvis man i en organisation observerer, at person B ændrer sin arbejdstilrettelæggelse, vil man måske se på de formelle magtstrukturer, og vurdere at det skyldes, at en anden person A har formel magt til at påvirke B. Denne formelle magt er imidlertid kontekstafhængig. Det kan være, at andre personer med mere magt intervenerer i den konkrete situation. Det kan også være, at der er en stærk modmagt, og at ændringen i arbejdstilrettelæggelse er i opposition til As formelle magt. En tredje mulighed er, at vi befinder os i en kontekst med stærk tradition for selvstyring, hvor B uafhængigt af A justerer sin arbejdstilrettelæggelse, måske efter inspiration fra eksterne aktører eller fagfæller. Et fjerde scenario kunne være, at A måske ønsker at påvirke B i en bestemt retning, men at der i den givne kontekst ikke er ressourcer til at gennemføre dette, og resultatet derfor bliver et andet. Mange flere muligheder kan tænkes, men pointen skulle være klar, nemlig at det langt fra er simpelt at afgøre kausale sammenhænge i en kompleks social virkelighed. Kontekstforhold spiller en central rolle for, hvornår påvirkningsmekanismer (her magtrelationer) virker i praksis. Problemstillingen forstærkes væsentligt, når 
man har at gøre med komplekse og længerevarende interventioner, som involverer mange forskellige aktører, som aktiveres på forskellige tidspunkter.

I vurderingen af litteraturen anlægges som regel en form for rangordning af evidensgrundlaget i de underliggende studier, hvor 'guldstandarden' er randomiserede, kontrollerede forsøg (RCTer) (Rieper \& Foss Hansen, 2007; Tanenbaum, 1993, 1994; Timmermans \& Berg, 2005). Tanken er her, at man ved at holde en række faktorer konstante i kontrollerede forsøg kan sandsynliggøre, at de fundne effekter kan generaliseres til en bredere population. Hvis man kan finde flere RCTere med ensartede resultater, styrker det naturligvis sandsynligheden for generalisering. Der kan imidlertid rejses kritik mod RCT, som det primære grundlag for medicinske teknologivurderinger. Det gælder særligt, når disse retter sig mod komplekse (sociale) teknologier, og organiseringen af teknologibrug, men nogle af punkterne gælder også mere generelt, og er for så vidt velkendte i litteraturen. Kritikken tager udgangspunkt i to argumenter. For det første, at den statistiske tilgang i sig selv kan indebære en problematisk logik, fordi den bygger på gennemsnitlige sandsynlighedsbetragtninger. RCT kan sige noget om, hvad der i gennemsnit virker for en udvalgt patientgruppe, men ikke hvad der virker for den specifikke patient, som skal behandles (Tanenbaum, 1994). Det forekommer eksempelvis ofte, at medicin er testet på patientgrupper med andre karakteristika end dem, som benytter medicinen. Medicin til ældre patienter er således ofte testet på yngre befolkningsgrupper, og slet ikke i den poly-farmeceutiske virkelighed, som mange ældre patienter befinder sig i. Hertil kommer, at stikprøverne ofte er relativt små, og at tidsperspektivet er begrænset. Dermed opfanger man ikke risici for langsigtede og sjældne bivirkninger.

For det andet, og mere centralt i forhold til organisationsaspektet er det, at RCT forudsætter ensartede organisatoriske vilkår (eller slet ikke behandler spørgsmålet om organisatoriske kontekstfaktorer), mens den praktiske virkelighed er langt mere heterogen, som beskrevet ovenfor. Dette bliver særligt vigtigt, når den medicinske teknologi indebærer komplekse interaktioner og omhandler patienter med meget individuelle behov. Typiske eksempler herpå er længerevarende patientforløb, eventuelt med co-morbiditet, som kræver samspil mellem flere behandlingsniveauer, og hvor unikke sociale omstændigheder spiller en rolle for forløbet.

I det følgende afsnit uddybes denne kritik. Herefter diskuteres om organisationsaspektet af medicinsk teknologivurdering (MTV) kan styrkes ved brug af realistisk evaluering, samt hvilke udfordringer, barrierer og muligheder der kan identificeres ved brug af realistisk evaluering til vurdering af komplekse (sociale) behandlingsteknologier. 


\section{MTV-tilgange og praksis}

MTV kan defineres som en særlig type anvendt evalueringsforskning af foreliggende viden om problemstillinger ved anvendelsen af teknologi i relation til sundhed og sygdom i forhold til specifikke patientgrupper (Van der Knaap et al., 2008). MTV betragtes typisk hverken som en disciplin eller et videnskabeligt felt, men betragtes snarere som en form for interdisciplinær proces, der er baseret på systematisk evidens og anden viden.

En MTV beskrives også ofte i litteraturen som en metode, der evaluerer ny og eksisterende behandlingsteknologi med det formål at give pålidelige input til beslutningstagere og til praksis om fordele og risici ved brugen af en eksisterende eller fremtidig teknologi (Banta, 2003; Maynard \& McDaid, 2003). MTV-analyser har således til formål at blive anvendt som input til policy- og praksisbeslutninger i sundhedsvæsenet, dvs. at forsyne de politiske beslutningstagere med information om politiske alternativer (Banta, 2009). MTV-målgruppen er siden hen blevet udvidet til at inkludere en langt bredere vifte af beslutningstagere, såsom klinikere, hospitalsledere og administratorer på sundhedsområdet.

Oprindelsen til MTV kan findes i USA i begyndelsen af 1960'erne, hvor der var en bred og stigende efterspørgsel efter viden om nye teknologier og deres effekter. MTV blev set som et vigtigt redskab til at imødegå denne efterspørgsel efter viden, som kunne hjælpe med at prioritere mellem de forskellige muligheder (Banta \& Luce, 1993). På sundhedsområdet blev de medicinske teknologivurderinger, som havde fokus på "effektivitet, sikkerhed og cost-effectiveness", udbredt i USA fra begyndelsen af 1970'erne (Banta, 2009). Forenklet sagt har MTV traditionelt stillet spørgsmålene, om en bestemt (medicinsk) teknologi virker bedre end andre, og har set på de økonomiske omkostninger forbundet med teknologien (Van Der Wilt \& Reuzel, 1998). Dette er stadig kernen i MTV-praksis, men tilgangen er særligt i nordeuropæiske lande over tid udvidet med mere nuancerede vurderinger af patientrelaterede, etiske og organisatoriske forhold.

Sundhedsteknologier inkluderer principielt en bred vifte af interventionsredskaber, såsom medicin, instrumenter, procedurer og organisatoriske og understøttende systemer, inden for hvilken sundhedsydelser leveres (Banta, 2009). Hvor de traditionelle MTV-analyser typisk havde et ret snævert fokus, er der i hvert fald i nogle dele af MTV-miljøerne udviklet en ambition om at inkludere bredere spørgsmål, der ikke alene relaterer sig til indførelsen af en bestemt ny type medicin eller en behandlingsform, men også adresserer den stadig mere komplekse, moderne sundhedssektor karakteriseret ved mere mangfoldig menneskelig aktivitet og nye tekno- 
logier og tilgange, der hele tiden kommer til (Forbes \& Griffiths, 2002). Men denne ambition stiller også store krav til de organisatoriske MTV-analyser, fordi det netop er organiseringen og sammenhængen mellem forskellige behandlingsaktører, som hermed kommer i fokus. Den eksisterende MTV-metodelitteratur har på forskellig vis søgt at finde teoretiske og metodiske perspektiver til at imødegå disse behov. I dansk sammenhæng er der således udarbejdet flere MTV-metodehåndbøger, som inkluderer organisationsteoretiske perspektiver. I praksis er der imidlertid stadig en usikkerhed i forhold til at anvende disse perspektiver på en systematisk måde. Organisationsanalyserne bliver ofte et begrænset vedhæng, som ikke i tilstrækkeligt grad formår at nuancere og befrugte de andre delanalyser. Dette skyldes ikke nødvendigvis svagheder ved de organisationsteoretiske perspektiver, men bunder nok i lige så høj grad i manglende træning i at anvende dem - særligt blandt sundhedsvidenskabeligt uddannede MTV-analytikere og begrænsede ressourcer. Ikke desto mindre kan der være god grund til at overveje, om alternative tilgange eventuelt kunne give en mere tilgængelig og systematisk ramme for organisatoriske MTV-analyser. I det følgende vil vi diskutere RE (realistisk evaluering), som én (blandt flere) mulige supplerende tilgange. Det primære argument er således, at det særligt for nogle interventionstyper, og særligt i forhold til organisationselementet i MTVer er relevant at afprøve alternative tilgange til analyserne.

Man kan forestille sig en skala med forskellige typer teknologier, hvor afgrænsede behandlingsinterventioner ligger i den ene ende. I forhold til denne type interventioner virker RCT relativt godt, med de ovennævnte generelle forbehold. Efterhånden, som man bevæger sig over i den anden ende af skalaen, bliver teknologierne mere komplekse og mere afhængige af interaktioner og fortolkninger på tværs af forskellige aktører. Variationsmulighederne bliver større, og mulighederne for at overføre resultater på tværs af kontekster bliver mindre.

Det ofte begrænsede grundlag af videnskabelige studier, til vurdering af økonomiske, organisatoriske og patientrelaterede teknologi aspekter, er et væsentligt problem. F.eks. var en konklusion i den nyligt publicerede MTV om diabetiske fodsår, at der kun fandtes få systematiske og generalisérbare studier af de organisatoriske forholds betydning for patient-outcome og omkostninger.

Et væsentligt spørgsmål er herefter, hvordan man med et rimeligt ressourceforbrug kan udvikle alternative tilgange, som kan tage højde for kompleksitet og kontekst, og på samme tid have gennemslag i forhold til en beslutningsproces, hvor der ønskes relativt entydige indspil.

Det forekommer, at jo mere komplekse interventioner bliver, jo mere udfordrende bliver spørgsmålet om, hvad der virker. Clarke (2006) argumenterer for, 


\begin{tabular}{|l|l|l|}
\hline & $\begin{array}{l}\text { Afgrænsede og relativt entydige } \\
\text { interventioner }\end{array}$ & \multicolumn{2}{|l|}{$\begin{array}{l}\text { Komplekse sociale teknologier } \\
\text { karakter }\end{array}$} & $\begin{array}{l}\text { Interventionen relativt uafhængig } \\
\text { af den enkelte patients særlige ka- } \\
\text { rakteristika. Forløbene er tidsmæs- } \\
\text { sigt afgrænsede, kan let standardi- } \\
\text { seres, og involverer et begrænset } \\
\text { antal lægefaglige aktører. }\end{array}$ & $\begin{array}{l}\text { Interventionen har karakter af en } \\
\text { socialt situeret anvendelse af en } \\
\text { ræke forskellige kliniske og ikke- } \\
\text { kliniske teknologier, og med høj grad } \\
\text { af individuel variation i timing og } \\
\text { sammensætning. }\end{array}$ \\
\hline $\begin{array}{l}\text { Eksempler på } \\
\text { teknologi }\end{array}$ & $\begin{array}{l}\text { Afgrænset elektiv kirurgi. } \\
\text { Enkeltstånde farmaceutiske inter- } \\
\text { ventioner. }\end{array}$ & $\begin{array}{l}\text { Komplekse og langvarige behand- } \\
\text { lingsforløb for kroniske lidelser så } \\
\text { som diabetes. } \\
\text { Behandling af ældre medicinske } \\
\text { patienter. } \\
\text { SundhedsIT og telemedicin. }\end{array}$ \\
\hline Metode tilgang & $\begin{array}{l}\text { Mulighed for brug af standardi- } \\
\text { serede vurderingsmetoder så som } \\
\text { RCT, - men stadig med varsomhed } \\
\text { ift betydningen af organisatorisk } \\
\text { kontekst. }\end{array}$ & $\begin{array}{l}\text { Standardiserede statistiske meto- } \\
\text { der så som RCT kommer til kort på } \\
\text { grund af den høje kompleksitet og } \\
\text { kontekstspecifikke variation. } \\
\text { Brug for alternative samfundsviden- } \\
\text { skabelige tilgange, som f.eks. RE. }\end{array}$ \\
\hline
\end{tabular}

at det kan være hensigtsmæssigt, at erstatte spørgsmål om "hvad virker?" med f.eks. "hvilke dele af interventionen 'virker', og på hvilken måde virker den?", når mere komplekse programmer skal evalueres. En mulighed kan være at rette blikket mod de såkaldt teoridrevne eller teoribaserede evalueringer, som vi diskuterer i næste afsnit.

\section{Teoridrevne evalueringer}

Evalueringsteoretikere som Chen \& Rossi (1987), Chen (1990), Weiss (1972; 1995; 1997), Pawson \& Tilley (1997) er alle eksponenter for en type evaluering, der lægger særlig vægt på, at teori burde spille en langt mere central rolle i evalueringer. Teoribaseret evaluering (TBE) ${ }^{4}$ præsenteres ofte som et alternativ til de mere metodeorienterede tilgange, der kritiseres for ikke at åbne 'the black box', dvs. forbindelsen mellem input/intervention og outcome. Scriven (1994) kalder teoridreven evaluering for 'white box'-evaluering, med hvilket der menes den type evaluering, der søger at pakke 'the black box' ud, sådan at de indre komponenter eller logikker $i$ et program kan undersøges. Det der forener de mange tilgange inden for TBE er rekonstruktionen af kausale modeller baseret på forskellige kilder, som led tilve- 
jebringelsen af en bedre forståelse af, hvordan en specifik intervention (eller et specifikt program) har som intention at generere, eller som genererer 'output' og 'outcomes' (Stame, 2004). Problemet opstår i særlig grad, når interventionerne går ud over rammerne for den medicinske eller monofaglige teori. Realistisk evaluering (RE) fremstår som et godt bud i denne situation, fordi den kan "gå på tværs" af traditionelle fagdiscipliner, og kan integrere dem i en kontekstsensitiv tilgang.

Kernen i teoridrevne evalueringer er en iterativ udvikling og afprøvning af programteorier. I denne iterative proces inddrages social kontekst og menneskelig fortolkning og handling som grundlag for udvikling og afprøvning af kontekstsensitive programteorier. Forbindelsen mellem intervention og outcome opfattes dermed som sammensat og dynamisk.

\section{Den kritiske realistiske evalueringsteori}

Realistisk evaluering (RE) er baseret på den såkaldte kontekst/mekanisme/outcome konfiguration (CMO) (Pawson \& Tilley, 1997). RE spørger ikke, "hvad virker?" eller "virker denne intervention?". Derimod spørger RE: "Hvad virker, for hvem virker det, hvordan virker det og under hvilke omstændigheder virker det? (Pawson \& Tilley, 1997). RE søger at tilvejebringe en forståelse af, hvordan en intervention producerer bestemte outcomes. Argumentet er, at en sådan viden, kan forbedre grundlaget for at sikre et bedre fokus og mere effektive interventioner. Effektiviteten af en social teknologi afhænger af de kausale mekanismers bevægelser, der i vid udstrækning afhænger af konteksten (Leeuw \& Astbury, 2010).

Tankegangen er, at bestemte kontekster, betinger kausale mekanismer, som igen enten medfører, eller ikke medfører, at det kausale potentiale realiseres i form af et kausalt outcome. Mekanismer antages at udgøre motoren bag bevægelsen, men mekanismer er vanskelige at observere i praksis.

Mekanismer er sensitive i forhold til variationer i konteksten, men også af eksistensen af andre mekanismer i en specifik kontekst. En mekanisme (M) kan derfor have et kausalt potentiale, der kun realiseres i nogle kontekster, men ikke i andre. Når denne egenskab fremhæves, er det fordi, at mekanismer i det store hele er afhængige af menneskelige ræsonnementer, fordi de virker gennem mennesker som aktører, der har den kognitive kapacitet til at tænke og handle i forhold til kausaliteter og som har evnen til at få ting til at ske (Leeuw \& Astbury, 2010). Sagt på en anden måde, så er mekanismer kontekstafhængige, fordi deres virke i den sociale verden er nært knyttet til menneskelig fortolkning af sociale strukturer og 
handling (Leeuw \& Astbury, 2010; Pawson \& Tilley, 1997). Derfor kalder Pawson og Tilley i evalueringssammenhæng interventioner for komplekse 'sociale' interventioner (eller sociale programmer). Sociale interventioner vedrører samspillet mellem handling og strukturer, individer og institutioner og mellem mikro- og makroniveauet. Gode medicinske studier tilnærmer sig denne kompleksitet ved at arbejde med 'interaktionseffekter', 'mediatorer' og 'confoundere' i de statistiske analyser. Pointen er imidlertid, at de kontekstspecifikke variationsmuligheder ved sociale teknologier er meget store, og vanskeligt lader sig oversætte til enkle confoundere mv., som uproblematisk kan applikeres i andre organisatoriske sammenhænge.

Med udvikling af teori om interventionen er målet at søge at forklare de komplekse fodspor, som programmet har sat, og man forventer at kunne afbilde et mønster i outcome, bestående af succeser og fiaskoer inden for og mellem interventioner. Mekanismer, kontekster og outcomes forudsætter følgelig en kompleks evidens. RE anbefaler derfor, at man principielt bør inddrage alle forskellige nøgleaktører, der hver især antages at vide noget om det, der evalueres. Dermed kan man udvikle en lokalt baseret tværgående teori om mekanismer og effekter (Pawson \& Tilley, 1997). Pawson og Tilley skelner mellem forskellige nøglepersoner: Subjekter (f.eks. patienter), praktikere (f.eks. læger) og beslutningstagere samt evaluator selv. Hver af disse nøgleaktører antages at have noget at lære de andre og lære af de andre.

RE anbefaler multiple datakilder og metoder som fundament for den komplekse evidens. Udvælgelsen af forskellige metoder og datakilder begrundes med muligheder og behov, og skal i hvert tilfælde afklares og specificeres nøje til de hypoteser, der udvikles (Ray Pawson \& Tilley, 1997). Metoderne og empirien i RE kan derfor være mange; herunder f.eks. dokumentanalyse, mødeobservationer, kvalitative og fokusgruppeinterview med nøgleaktører fra praksis, dokumenter og administrative registreringer og kvantitative metoder.

Første trin i en RE-analyse er opbygningen af hypoteser, der skal forholde sig til hvad der virker, for hvem og under hvilke omstændigheder (dvs. om mekanismer og deres relation til kontekst). Hypoteserne opbygges iterativt og formaliseres løbende. Når hypoteserne har fået form, testes hypoteserne systematisk gennem inddragelse af data, hvilket kan være f.eks. interviews med programarkitekter og praktikere, samt læsning af centrale evalueringsstudier og relevant videnskabelig litteratur. I denne proces formuleres tankerne om, hvordan et program virker. Dvs. en teori om praksis, hvorefter teorien testes gennem anvendelse af forskellige metoder. Programteorierne udbygges og formaliseres gennem grundig empiri- 
indsamling, hvor evaluator kan benytte de mange metoder, som er til rådighed. Alt det data, der genereres, kan benyttes til at 'teste teorien', hvilket ideelt set atter fører til en revision af teorien. Nedenfor ses strategien afbildet, som en cirkulær proces, der i princippet aldrig slutter, fordi teorien altid kan efterprøves med henblik på at forbedre den.

\section{Realist evaluation as hypothesis testing}

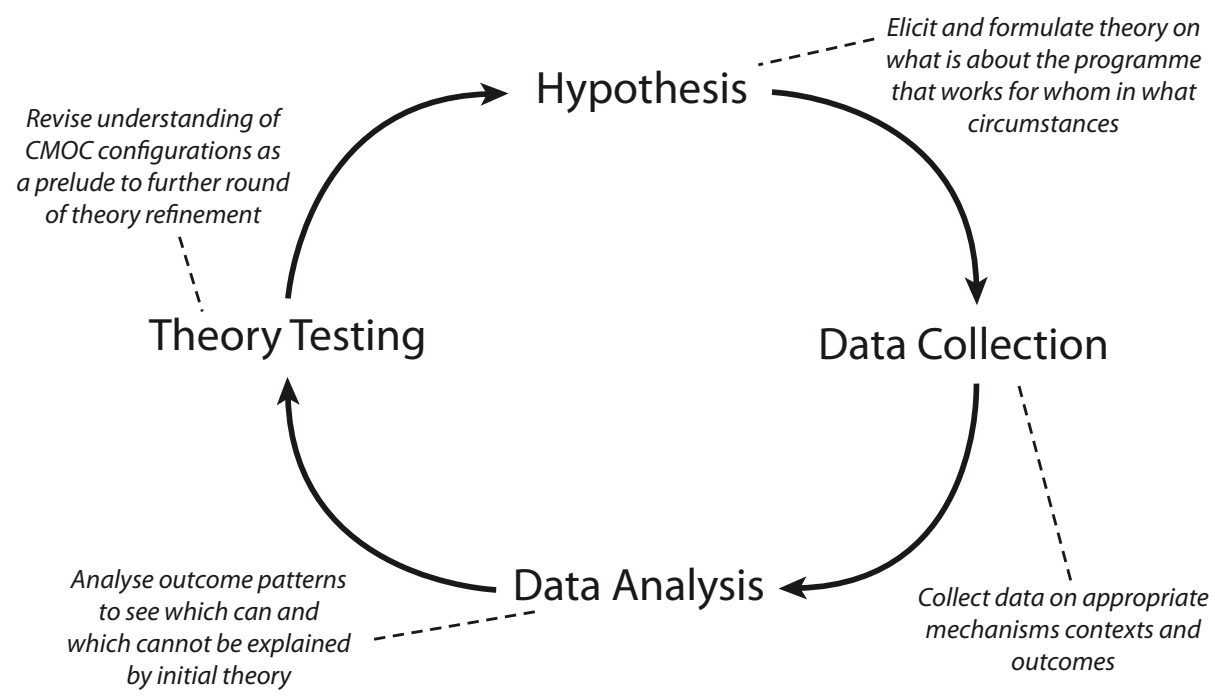

Hentet fra Pawson \& Tilley 2004

Pawson (2006) og Pawson \& Tilley (1997) kritiserer studier baseret på RCT (og kvasieksperimentelle tilgange) for ikke at producere den mest relevante viden om sociale interventioner. I vores forstand menes hermed interventioner, som har en dynamisk og kompleks karakter, og indebærer kombinationer af kliniske og ikkekliniske elementer. I sådanne tilfælde er der brug for en nuanceret og lokalt udviklet programteori, som tager højde for den praktiske variation.

Det er vigtigt at have øje for de sociale og adfærdsmæssige aspekter i de interventioner, som undersøges. Pawson og Tilleys påstand er, at (nogen) fortalere for eksperimenter ser interventioner som 'black boxes', men for at forstå hvorfor ting virker, er man nødt til at vide hvilke sociale og adfærdsmæssige mekanismer, der er aktive og i hvilke kontekster. Det er vigtigt, at man i et komplekst genstandsfelt anerkender, at 'kontekst' kan spille en stor rolle for outcome.

At interventioner er åbne systemer, der forandres gennem læring, og efterhånden som nøgleaktører forstår dem, skal forstås sådan, at de kausale kræfter ikke 
befinder sig i de specifikke programmer, men derimod i de sociale relationer og organisatoriske strukturer, der er en del af et større socialt system. Det er netop udfordringen i den organisatoriske analyse i en MTV at undersøge, hvor der findes ligheder og forskelle i organisatoriske betingelser for at anvende og benytte komplekse medicinske teknologier. Kompleksiteten i sociale interaktioner bør give anledning til at overveje nye typer tilgange til at frembringe viden, som f.eks. RE. I det følgende præsenteres en nylig MTV af behandling for diabetiske fodsår som eksempel på en organisatorisk MTV, hvor RE kunne have bidraget. Det skal understreges, at analysen er gennemført uden systematisk brug af RE men med brug af organisationsteoretiske perspektiver, som i lighed med RE lægger vægt på at forstå kontekstspecifik teknologianvendelse. Pointen med gennemgangen er således at illustrere problematikker, der kan forekomme ved at evaluere komplekse sociale teknologier, og dernæst at antyde hvordan RE kunne have styrket analysen yderligere.

\section{Et eksempel på organisationsteoretisk analyse af komplekse interventioner}

MTVen om diabetiske fodsår er et aktuelt eksempel på en MTV, der har beskæftiget sig med et komplekst problemfelt, hvor kliniske og ikke-kliniske teknologier spiller sammen i varierede patientforløb (Sundhedsstyrelsen, 2011).

Organiseringen af diagnostik og behandling af diabetiske fodsår er komplekst, fordi patientforløb typisk går på tværs af sektorer, og berører en lang række forskellige fagpersoner og fagligheder. Behandlingen af diabetiske fodsår kan involvere almen praksis, praktiserende speciallæger, regionale sygehusafdelinger og specialiserede sygehusafdelinger (f.eks. sårcentre), fodterapeuter og kommunale sundheds- og socialaktører. Efter strukturreformen, hvor kommunerne har fået flere og nye roller på sundhedsområdet, er samspillet mellem myndighedsniveauer blevet vigtigere.

Det stiller store krav til organiseringen og til kommunikationen, hvilke er nødvendige for at opnå gode forløb for den enkelte patient. Et sår hos en person med diabetes kan hurtigt blive meget alvorligt. I værste fald kan det ende med amputation, hvis man ikke kommer i behandling, og den rette viden bliver bragt i spil på rette tid. Der er tale om et problemfelt, hvor udviklingsforløb kan være meget forskelligartede, hvilket samtidigt stiller store krav til såvel behandlingssystemet, som patienternes egen ageren i forhold til deres sår. Som patient skal man ikke 
kun forholde sig til såret, men også til et komplekst system af behandlere og et ofte langvarigt forløb, samtidig med at man skal håndtere og mestre den bagvedliggende kroniske lidelse, diabetes.

Hovedformålet med den organisatoriske MTV var at understøtte den generelle MTV ved for det første at undersøge, hvordan diagnostik og behandling af diabetiske fodsår er organiseret i Danmark. Der fandtes ikke et samlet overblik over organiseringen af patientforløb og behandlingsmuligheder i de forskellige dele af landet, så der var ikke på forhånd et hverken bredt eller dybtgående vidensgrundlag for at vurdere teknologianvendelsen. Samtidigt med denne kortlægning gennemførtes for det andet en indsamling af aktørbaserede vurderinger af muligheder og barrierer for optimal klinisk tilrettelæggelse med den eksisterende organiseringsform. En systematisk søgning efter dansk og international litteratur blev benyttet som baggrund for at udvikle spørgsmål (temaer) og fortolke resultater. I RE-termer kan man sige, at der blev gennemført en kontekstnær vurdering af, hvordan behandlingen for diabetiske fodsår er organiseret $\mathrm{i}$ forskellige dele af landet, og i forhold til de forskellige faser i et patientforløb (diagnosticering, behandling, opfølgning og monitorering). Denne viden kunne i RE-termer være oparbejdet til en slags 'programteori' om sammenhænge mellem organiseringselementer og (aktørbaseret) forståelse af konsekvenser, som så kunne være efterprøvet i praksis. På grund af ressourcebegrænsninger nøjedes MTVen dog med at pege på en række opmærksomhedspunkter i forhold til organisering, hvor der ud fra en samlet vurdering af aktørudsagn og sekundær litteratur kunne være særlige fordele og ulemper ved bestemte organisationselementer. Disse opmærksomhedspunkter blev afprøvet og videreudviklet ved møder med følge- og projektgrupper for MTV-projektet.

Kunne et realistisk evalueringsperspektiv så yderligere have understøttet en MTV på dette område? For at åbne op for denne diskussion, vil vi skelne mellem de 'interne' og de 'eksterne' forhold. De interne forhold drejer sig, dels om (1) det ressourcemæssige aspekt i forhold til metodevalg og dataindsamling, dels om (2) at syntetisere/sammenlægge evidensen fra flere forskellige videnskabsparadigmer i de forskellige dele af en MTV. Hvad angår de 'projekteksterne forhold', drejer det sig om, (3) i hvilken udstrækning den kontekstbaserede og dermed mere nuancerede 'realistiske' viden kan opnå legitimitet og levere input med tilstrækkelig gennemslagskraft til beslutningstagningsprocessen på det politiske, administrative såvel som det kliniske niveau. Spørgsmålet er, om man kan skabe en viden, der både har evnen at informere praksis og beslutningstagerne, eller om man spilder kræfterne ved at forsøge at ride på to heste samtidig? 


\section{Metodevalg og dataindsamling}

Projektledelsens oprindelige tilsigtede udgangspunkt for MTVen om diabetiske fodsår (Sundhedsstyrelsen, 2011) var at lave en MTV med udgangspunkt i fire dele: Patient, organisation, økonomi og teknologi efter den danske MTV-model. Man stillede spørgsmålet: Hvordan etablerer man det bedst mulige grundlag for diagnostik og behandling af mennesker med diabetiske fodsår? Ambitionen var at levere relevant, alsidig evidensbaseret viden om:

1. effekten af diagnostik og behandling af diabetiske fodsår.

2. patienters oplevelse af sygdommen og af organiseringen af diagnostik og behandling.

3. de økonomiske omkostninger ved diabetiske fodsår.

4. den nuværende organisering, og om hvordan diagnostik og behandling hensigtsmæssigt tilrettelægges fremover (Sundhedsstyrelsen, 2011).

Allerede i planlægningsfasen blev projektledelsen og de øvrige involverede opmærksomme på en høj grad af kompleksitet på området, og der var udbredt enighed om, at det var et vigtigt selvstændigt bidrag fra MTVen at analysere, hvordan diagnostik og behandling var organiseret, og bedst kunne organiseres fremover. Det blev derfor indarbejdet som en del af projektets formål, at det skulle udgøre et konstruktivt bidrag til vurderingen af, hvorvidt der er behov for at tilpasse organiseringen og for at udarbejde nationale kliniske retningslinjer på området. Følgende undersøgelsesspørgsmål blev formuleret for organisationsdelen i forlængelse af denne erkendelse:

1. Hvordan er diagnostik og behandling af diabetiske fodsår organiseret i Danmark?

2. Hvilke barrierer og muligheder kan identificeres i den nuværende organisering?

3. Hvilke konkrete forslag til fremtidige indsatser kan identificeres med henblik på at opnå en hensigtsmæssig organisering?

Disse spørgsmål sigtede mod at adressere den høje grad af kompleksitet ved at fokusere på samspilsrelationer og kommunikation. Udgangspunktet for organisationsanalysen i MTVen var dermed, at patientforløbstankegangen blev tænkt ind i alle dele af projektforløbet for at kunne analysere, hvilke aktører der gjorde hvad i de forskellige faser, og hvordan overgange mellem forskellige behandlingsaktører og myndighedsniveauer var organiseret i praksis. Analysen skelnede mellem 
en diagnostisk fase, en behandlende fase med eventuel kirurgisk intervention og en efterbehandlingsfase med genoptræning og forebyggelse af yderligere skader (Sundhedsstyrelsen, 2011). Det viste sig, at de enkelte teknologier i sig selv var relativt velkendte, men at der var forbavsende få systematiske studier om virkningsgraden, og relativt ringe konsensus om visse teknologielementer. Endvidere kunne det konkluderes, at den sammenhængende diagnostik og behandling på ingen måde var ukompliceret. Tværtimod blev det en hovedkonklusion at organiseringen af patientforløb, og dermed hvordan og hvornår de forskellige teknologielementer blev bragt i spil, var helt central.

Den indledende litteratursøgning for organisationsanalysen fandt meget få systematiske undersøgelser af forskelle i muligheder for at realisere kliniske effekter under forskellige organisatoriske alternativer. De få, som fandtes, var af begrænset kvalitet, og kunne kun med væsentlige forbehold overføres til en dansk kontekst. Meget af litteraturen byggede på enkeltstående ekspertudsagn og opsummeringer af case erfaringer, men var uden tilstrækkelig redegørelse for eventuel bias eller generaliseringsmæssige begrænsninger. Heller ikke den fundne kliniske eller økonomiske litteratur gav tilstrækkelig systematisk afdækning af organisatoriske alternativer og deres fordele og ulemper. På grund af den manglende litteratur blev det vigtigt at finde en anden strategi, hvor ekspertinterviews med aktører i feltet kom til at stå centralt.

Den manglende evidens kan ses som et symptom på kompleksiteten af den type af problemstilling, som organisationsanalysen stod overfor. Det understøtter også de mere generelle betragtninger om vanskelighederne ved at basere sig på traditionelle metodetilgange så som metareviews og RCT i arbejdet med organisatoriske problemstillinger. Særligt som i dette tilfælde hvor interventionen er meget svær at adskille fra den organisatoriske kontekst, fordi det netop handler om sekvensering og ressourceallokering i forhold til individuelle behandlingsforløb. Mere populært kan man sige at teknologien i dette tilfælde handler om, hvem der gør hvad, på hvilken måde og hvornår?

Som supplement til det begrænsede udvalg af solide eksisterende studier valgtes en strategi med kombination af skriftlige forvaltningsdokumenter og ekspert- og fokusgruppeinterview i hver region. Til besvarelse af spørgsmål 1 anvendtes følgende empiriske dele: regionernes forløbsbeskrivelser for diabetes/ diabetiske fodsår, regionernes hjemmesider, samt telefoninterviews med repræsentanter for alle de regionale diabetesudvalg. Til besvarelse af spørgsmål 2 og 3 , benyttedes fokusgruppeinterviews med centrale aktørgrupper (dvs. regionale 
og kommunale faglige eksperter - alle med direkte patientkontakt). Herigennem var hensigten at få indsigt i aktørernes opfattelser af de forskellige formelle såvel som uformelle organiseringsselementer. Fokusgruppeinterview blev valgt for at få indblik i centrale problemstillinger set fra flere forskellige aktørgruppers side og i et samlet patientforløbsperspektiv. Det var en vigtig del af interviewene at afsøge aktørernes vurderinger af og erfaringer med barrierer og muligheder (mekanismer) for en hensigtsmæssig organisering, samt deres fortolkninger af betydningen af de eksisterende samarbejdsstrukturer og organisatoriske praksisser i hver region. Ideen med at foretage fokusgruppeinterviews med centrale aktører på området var således at undersøge, hvilken betydning forskellige kontekster har for forskellige mekanismer. Hvis man følger RE, antages det, at de centrale aktørers udsagn er resultater af, at programmet (den samlede diabetiske fodsårsbehandling) stiller bestemte ressourcer til rådighed for aktørerne, som så fortolker/handler og får erfaringer ud fra dette program. I dette tilfælde gennemførtes et fokusgruppeinterview i hver region, og deltagerne var praktikere (ledende afdelingslæger, sårsygeplejersker, kommunale sygeplejersker, fodterapeuter og APL). Disse kunne give et billede på de forskellige regioners arbejde med behandling af patienter med diabetiske fodsår. De kvalitative interview spillede dermed en betydelig rolle i forhold til at bringe programmets teori frem via 'programarkitekterne' og praktikere i det undersøgte felt. Organisationsanalysen i MTVen om diabetiske fodsår har dermed mange træk, som stemmer overens med en RE-tankegang, selvom den ikke eksplicit refererede hertil. Den illustrerer dermed også nogle af udfordringerne ved en RE baseret analyse. En mere systematisk anvendelse af RE ville have krævet et endnu mere omfattende empirisk arbejde for at opstille, verificere og justere programteorier. Det ville således have været nyttigt at udvælge en række kliniker, sundhedsfaglige ledelser på sygehuse og i regionerne og eventuelt nogle cases i form af patientforløb. Dette ville selvsagt kræve en del flere ressourcer og meget mere tid, end der var til rådighed i dette projekt.

Trods begrænsningerne gjorde de anvendte kilder det muligt for at afprøve fortolkninger af praksis og kontekstuelle vilkår. Denne nuancerede forståelse af de kontekstuelle vilkår åbnede op for muligheden for en diskussion af organiseringen af behandlingen af diabetiske fodsår. Dermed understreges også potentialet for at bruge RE-tilgange til at frembringe mere detaljeret og konktekst-sensitiv data om teknologianvendelse. 


\section{Sammenvejning af evidens i MTV}

MTV har hidtil ikke udviklet en tilgang at syntetisere evidens fra divergerende paradigmer, som en MTV som regel består af. Det medfører i realiteten, at samspillet mellem de forskellige dele af MTVen, kun i lille udstrækning finder sted i praksis. Evalueringsfeltet har udviklet en række nye tilgange til at foretage sådanne synteser, og Pawson (2006) giver et bud på en sådan ramme. 'Realist synthesis' (RS) er en tilgang udviklet af Pawson (2006) til at foretage reviews af forskningsevidens, der vedrører komplekse sociale interventioner. Tilgangen er ny, relativt uafprøvet og under udvikling. Den minder om traditionelle reviewprocedurer fra Cochrane og Campbell, men en væsentlig forskel er, at man i analysen deler interventionen op i komponentteorier. Målet er for så vidt det samme som i RE, nemlig at artikulere en underliggende programteori, men her undersøges eksisterende evidens, dvs. primærstudier. Teorierne kan altså hele tiden afprøves og revideres. Det er klart, at noget evidens vedrører kontekst, noget mekanismer og andet outcome, og ideen i reviewet er, at man sammenstiller disse evidenstyper, og undersøger om f.eks. proces-viden i et studie, kan give mening til data om outcome i et andet studie (Pawson, 2006). I det foreliggende studie kunne man forestille sig, at der opstilles en programteori, som på baggrund af beskrivelser af variation i kontekstuelle forhold (forekomsten af en central hospitalsenhed for sårbehandling, forekomsten af forskellige typer specialister, forskellig brug af telemedicin for monitorering af sår mv) kunne forenes med procesbeskrivelser (patientforløbsanalyser, analyser af henvisningspraksis og ventetid) i forhold til forklaring af forskelle i kliniske outcome variable (antal amputationer, antal bevægelser fra lavere til højere klassificering af sår). Pointen er så, at programteorien løbende udfyldes og revideres, efterhånden som flere studier bidrager. Det kan indebære en meget stor opgave at indsamle og systematisere (i princippet) alle studier, som kan bidrage til udviklingen af teorierne i interventionerne. I det foreliggende tilfælde var problemet dog, at der kun fandtes relativt få relevante studier, og at teori om kontekst, mekanismer og effekter derfor skulle konstrueres ud fra aktørudsagn. Den type dataindsamling er langsommelig og ressourcekrævende.

Uanset hvilke datatyper der anvendes, må processen med bearbejdning og revision på et givent tidspunkt afsluttes, og det kræver evaluators vurdering. Udvælgelseskriterierne er ifølge Pawson og Tilley, at man vælger studier, såfremt de vurderes til at kunne bidrage til at forfine de analytisk definerede programteorier. En vurdering, som Pawson (2006) argumenterer for, sker i alle typer reviews og kræver en blanding af stor erfaring og skarpsindighed. 
Syntesen mellem de forskellige dele af analysen, er som nævnt en uløst udfordring for MTV og RS kunne være et muligt bud på, hvordan man kunne få forskellige typer af evidens i en MTV til at hænge sammen med en samlet programteori.

\section{Kan realistisk evalueringsviden skabe gennemslagskraft på beslutningsniveau?}

Realistiske evalueringsdesign har en række umiddelbare fordele, men udgør ikke nødvendigvis den ultimative og eneste løsning på, hvordan vi adresserer komplekse MTV-spørgsmål. Der kan dog peges på nogle klare potentialer, som det synes værd at udforske. Først og fremmest er det afgørende, at MTV anses som et legitimt beslutningsgrundlag for beslutningstagerne. Dette kræver, at den viden der produceres, også opfattes som anvendelig på det politiske, administrative såvel som på det kliniske område. Den type af viden, som man producerer med realistisk teoretisk forankrede MTV-analyser, vil være af en noget anden karakter, end den viden de aktuelle MTVer producerer. Kan den realistiske evaluering med dens fokus på kontekstuel og nuanceret viden informere beslutningstagerne tilstrækkeligt (og bedre end eksisterende MTVer?), og har de gennemslagskraft nok? Det er formentlig urealistisk, og næppe heller ønskeligt at RE skulle erstatte RCT generelt - og det i særdeleshed tilfældet på de kliniske dele af MTVen. Men det kan bruges som supplement, hvor RCT har vist sig vanskelig at gennemføre, eller hvor der er problemer med RCT. Dette gælder f.eks. på organisatoriske problemstillinger og tværfaglige problemstillinger, hvor realisering af klinisk effekt afhænger af organisatoriske omstændigheder.

Det synes oplagt at medtænke kontekstuelle forhold i evalueringsdesign på sundhedsområdet, men en sådan type viden åbner også for fundet af et væld af lokale variationer på tværs af f.eks. regioner og sygehuse. Denne type variation kan til dels håndteres via afgrænsninger og statistiske kontroller for forskellige omstændigheder mv. i traditionelle studier. Dog når man i tillæg hertil inddrager REs fokus på dynamiske processer, hvor lokal kontekst spiller sammen med aktørfortolkninger, bliver variationsmængden og usikkerheden potentielt for stor til, at disse størrelser kan håndteres med statistiske metoder. Dette kan komme i konflikt med MTV-perspektivets ambition om at levere forholdsvis entydige indspil til beslutningstagning.

Pawson og Tilley (2004) peger på, at der alligevel er meget værdi i den type forklarende og kontekstnære viden, som oplæg til beslutningsprocesser. Pointen er, at 
den akkumulerede viden fra mange studier af kontekst-mekanismesammenhænge kan åbne 'den sorte boks' og skabe nye teoretiske idéer, som kan informere beslutningstagen. REs kritiske insisteren på kontekst, og på at aktører interagerer med og tilpasser sig til politikker og programmer, giver et mere nuanceret billede af de sociale sammenhænge, som er med til at skabe betingelser for gode eller dårlige resultater i sundhedssektoren. Det billede kan derfra give et nyttigt og nødvendigt supplement til andre metoder i form af en belysning af mulige forklaringer på de observerede forskelle. Vi kommer med andre ord tættere på at forstå de komplekse kausale sammenhænge, når vi gives varierende kontekster, end når vi blot konstaterer en sammenhæng mellem en givet intervention og et sæt givne resultater.

\section{Konklusion}

Forskningsspørgsmålet i artiklen var at diskutere, om medicinsk teknologivurdering (MTV) af komplekse (sociale) behandlingsteknologier kan styrkes ved brug af realistisk evaluering? Hvilke udfordringer, barrierer og muligheder kan der identificeres ved brug af realistisk evaluering til vurdering af komplekse behandlingsteknologier?

Vi har indledningsvis påpeget en række svagheder knyttet til EBM standarder, som i et betydeligt omfang lægges til grund for især den kliniske del af MTV-analyserne. Mange MTVer fokuserer hovedsageligt på netop de kliniske spørgsmål eventuelt suppleret med sundhedsøkonomiske vurderinger. Den i EBM benyttede 'guldstandard' er systematiske litteraturgennemgange og RCT-studier. Dette giver god mening for en væsentlig del af de kliniske fænomener, som skal undersøges. Der er imidlertid også svagheder. Det gælder generelt i forhold til metodens statiske karakter. RCT bygger ofte på en begrænset tidsperiode, og på et begrænset udsnit af testpersoner, som ikke altid er repræsentative i forhold til den gruppe, som efterfølgende berøres af interventionen.

Et andet væsentligt kritikpunkt er, at RCT ikke er velegnet til at tage højde for kontekstuelle forskelles betydning, med mindre de tydeligt kan beskrives og standardiseres. Imidlertid er samspillet mellem kontekst og aktørers handlen sjældent velbelyst, og det kan være svært at afgøre hvilke dele af konteksten, der skal lægges vægt på i forhold til følsomhedsanalyser mv. Dette gælder særligt for komplekse sociale teknologier, hvor variationsmulighederne i behandlingsforløb og organiseringsformer er særlig stor, og det derfor er vanskeligt at tage højde for alle kombinationsmuligheder i en statistisk analyse. 
Et tredje kritikpunkt er, at hvor de statistiske metoder er meget gode til at finde sammenhænge mellem intervention og output (under forskellige betingelser), så er de knap så gode til at finde forklaringer på disse sammenhænge. Der er med andre ord brug for supplerende forståelser af de ofte komplekse mekanismer, som er med til skabe denne sammenhæng. Medicinsk videnskab har naturligvis mange teorier om sammenhæng, men kommer ofte til kort, når det gælder interventioner, som kombinerer kliniske og sociale teknologier i komplekse behandlingsforløb f.eks. sundhedsIT eller behandling af komplekse, kroniske lidelser.

Det er i forhold til de to sidste problematikker, at organisationsanalysen kan træde ind, som et vigtigt supplement, særligt når der er tale om komplekse og sociale teknologier. Pointen er her, at organisationsanalyse kan bidrage med viden om, hvordan den organisatoriske kontekst spiller ind på kliniske processer, og muligheder for at opnå kliniske effekter. Denne type viden bliver særlig vigtig, når man har at gøre med komplekse, sociale teknologier, som i deres natur er mindre bestemte, og dermed mere åbne for mere mangfoldighed og flere typer af dynamiske interaktionsprocesser mellem kontekst, aktører og teknologi.

Vi har præsenteret RE, som et blandt flere mulige teoretiske perspektiver, som kan bruges som ramme for organisatoriske MTV-analyser. De særlige fordele ved RE er dens dynamiske karakter, dens vægt på kontekstrelationer, og dens insisteren på en eklektisk tilgang til at etablere programteori på baggrund af tværfaglighed og lokalt baserede perspektiver.

RE indebærer dog også en væsentlig ressourcemæssig investering, som skal holdes op imod de forventede gevinster. RE har ikke et klart bud på, hvornår den iterative proces med dataindsamling og revision af 'teori' skal afsluttes. Det vil være op til en konkret vurdering i det enkelte studie.

I forhold til spørgsmålet om syntetisering konkluderede vi, at MTV i sin nuværende udformning er uafklaret. Der er ikke tydelige anvisninger af, hvordan de kliniske, sundhedsøkonomiske, organisatoriske og patientrelaterede resultater skal spille sammen. I praksis lægges der typisk mest vægt på de to første elementer. Her mener vi, at RE har et muligt bidrag, idet der peges på strategier til at skabe syntese ved at bringe forskellige typer analysetilgange i spil som delelementer i formulering og afprøvning af 'teorier' om kausalitetsmekanismer under forskellige kontekstuelle omstændigheder. Resultatet bliver et rigt datamateriale, som ikke vægter de forskellige tilgange, men kan bruge dem alle til at besvare de mere komplekse spørgsmål om, hvordan teknologien virker, for hvem og under hvilke omstændigheder.

Kompleksiteten i svarene er både en fordel og en ulempe i forhold til det tredje vurderingskriterium om legitimitet og gennemslag i forhold til beslutningstagere. 
Formentlig giver den nuancerede og kontekstsensitive viden god mening for lokale beslutningstagere, mens det kan være vanskeligere at håndtere for beslutningstagere på højere niveau, som skal træffe beslutninger med gyldighed på tværs af forskellige lokaliteter. Sagt på en lidt anden måde vinder man formentlig i forhold til realismen af resultaterne og de konkrete organisatoriske kontekster. Der tabes dog også i forhold til at give generelle svar på hvilken teknologianvendelse, der virker bedst ud fra en absolut betragtning. Omvendt kan man sige, at udviklingen, af en bedre forståelse af kontekstuelt baserede mekanismer for at skabe resultater, kan hjælpe til at pege på organiseringsformer og forudsætninger for resultater, som kan efterlignes og afprøves andre steder. Man får med andre ord et mere nuanceret grundlag for at forstå de organisatoriske betingelser, som skal være til stede (eller etableres) for at opnå samme resultater, som de der forekommer på de bedst fungerende lokaliteter.

\section{Noter}

1: På engelsk Health Technology Assessment (HTA)

2: Til hvilken forfatterne til denne artikel har bidraget med organisationsanalysen

3: Randomized Controlled Trials eller randomiserede, kontrollerede studier

4: På engelsk ofte kaldet "theory-based evaluation" og beskrives ofte "program theory", "logic models", "theory-driven".

\section{Litteratur}

Banta, D. (2003). The development of health technology assessment. Health Policy, 63, 121-132. Banta, D. (2009). What is technology assessment? International Journal of Technology Assessment in Health Care, 25, 7-9.

Banta, D. H., \& Luce, B. R. (1993). Health Care Technology and its Assesments - An International Perspective. New York: Oxford University Press.

Chen, H. T. (1990). Theory-driven evaluations. Newbury Park: CA: SAGE.

Chen, H. T., \& Rossi, P. H. (1987). The theory-driven approach to validity. Evaluation and Program Planning, 10, 95-103.

Clarke, A. (2006). Evidence-based Evaluation in Different Professional Domains: Similarities, differences and challenges. In Shaw, I., Greene, J., \& Mark, M. (Eds.), Handbook and Evaluation, Policies, Programs and Practices: SAGE Publications.

Connelly, J. (2001). Critical realism and health promotion: effective practice needs an effective theory. Health Education Research, 16, 115-120. 
Draborg, E., Gyrd-Hansen, D., Poulsen, P. B., \& Horder, M. (2005). International comparison of the definition and the practical application of health technology assessment. International Journal of Technology Assessment in Health Care, 21, 89-95.

Forbes, A., \& Griffiths, P. (2002). Methodological strategies for the identification and synthesis of 'evidence' to support decision-making in relation to complex healthcare systems and practices. Nursing Inquiry, 9, 141-155.

Fulop, N., Allen, P., Clarke, A., \& Black, N. (2003). From health technology assessment to research on the organisation and delivery of health services: addressing the balance. Health Policy, 63, 155-165.

Kristensen, F. B., \& Sigmund, H. (2008). Health Technology Assessment Handbook. Copenhagen: Danish Centre for Health Technology Assessment, National Board of Health.

Leeuw, F. L., \& Astbury, B. (2010). Unpacking Black Boxes: Mechanisms and Theory Building in Evaluation. American Journal of Evaluation, 31, 363-381.

Maynard, A., \& McDaid, D. (2003). Evaluating health interventions: exploiting the potential. Health Policy, 63, 215-226.

Pawson, R. (2006). Evidence-based policy: A realist perspective. London: Sage Publications.

Pawson, R., \& Tilley, N. (2004). Realist Evaluation. Paper funded by the British Cabinet Office.

Pawson, R., \& Tilley, N. (Eds.) (1997). Realistic Evaluation. London: Sage Publications.

Rieper, O., \& Foss Hansen, H. (2007). Metodedebatten om evidens. København: AKF.

Scriven, M. (1994). The fine line between evaluation and explanation. Evaluation Practice, $15,75-77$.

Sundhedsstyrelsen. (2011). Diabetiske fodsår - en medicinsk teknologivurdering. Medicinsk Teknologivurdering København: Sundhedstyrelsen - Sundhedsdokumentation.

Tanenbaum, S. J. (1993). What physicians know. New England journal of medicine, 329.

Tanenbaum, S. J. (1994). Knowing and acting in medical practice: the epistemological politics of outcomes research. Journal of health politics, policy and law, 19, 27-44.

Timmermans, S., \& Berg, M. (2005). The Gold Standard: The Challenge ofEvidence-based Medicine and Standardization in Health Care. Philadelphia: PA: Temple University Press.

Van der Knaap, L. M., Leeuw, F. L., Bogaerts, S., \& Nijssen, L. T. J. (2008). Combining Campbell Standards and the Realist Evaluation Approach. American Journal of Evaluation, 29, 48-57.

Van Der Wilt, G. J., \& Reuzel, R. (1998). Assessment of Health Technologies: Which Issues Should be Addressed? Evaluation, 4, 351-358.

Weiss, C. H. (1972). Evaluation. Upper Saddle River: NJ: Prentice Hall.

Weiss, C. H. (1995). Nothing as practical as good theory. In Connell, J., Kubisch, A., Schorr, L. B., \& Weiss, C. H. (Eds.), New approaches to evaluating community initiatives. New York: NY: Aspen Institute.

Weiss, C. H. (1997). Theory-based evaluation: Past, present, and future. New directions for evaluation (No. 76). New Directions for Evaluation, 76, 41-55. 